Data Article

\title{
Sorption studies of methyl red dye removal using lemon grass (Cymbopogon citratus)
}

\author{
Mohd Azmier Ahmad ${ }^{a}$, Nur'Adilah Binti Ahmed ${ }^{a}$, Kayode Adesina Adegoke ${ }^{\mathrm{b}, \mathrm{c}}$, \\ Olugbenga Solomon Bello ${ }^{\mathrm{b}, \mathrm{d}, *}$ \\ a School of Chemical Engineering, Engineering Campus, Universiti Sains Malaysia, 14300 Nibong Tebal, Penang, Malaysia \\ ${ }^{\mathrm{b}}$ Department of Pure and Applied Chemistry, Ladoke Akintola University of Technology P.M.B 4000, Ogbomoso, Oyo State, Nigeria \\ ${ }^{\mathrm{c}}$ Department of Chemistry, University of Pretoria, Pretoria 0002, South Africa \\ ${ }^{\mathrm{d}}$ Department of Physical Sciences, Industrial Chemistry Programme, Landmark University, Omu-Aran, Nigeria
}

\section{A R T I C L E I N F O}

\section{Article history:}

Received 10 December 2018

Revised 10 June 2019

Accepted 16 June 2019

Available online 24 June 2019

\section{Keywords:}

Lemongrass leaves

Adsorption

Methyl red

\begin{abstract}
A B S T R A C T
Lemongrass leaf based activated carbon (LGLAC) was prepared using physico-chemical methods for methyl red (MR) dye removal from aqueous solutions. The surface chemistry of LGLAC before adsorption revealed the presence of different functional groups: 0 $\mathrm{H}, \mathrm{C}-\mathrm{H}, \mathrm{C}=\mathrm{O}, \mathrm{CH}_{3}, \mathrm{C}=\mathrm{C}, \mathrm{N}-\mathrm{O}, \mathrm{C}-\mathrm{O}$ and $\mathrm{C}-\mathrm{N}$ which were shifted after methyl red dye adsorption. Brunauer-Emmett-Teller surface and mesopore areas are $836.04 \mathrm{~m}^{2} / \mathrm{g}$ and 598.6 $04 \mathrm{~m}^{2} / \mathrm{g}$, whereas, the average pore diameter and total pore volume of LGLAC are $3.62 \mathrm{~nm}$ and $0.472 \mathrm{~cm}^{3} / \mathrm{g}$ respectively. Batch adsorption was studied using different parameters: initial dye concentrations $(25-500 \mathrm{mg} / \mathrm{L})$, contact time $(0-24 \mathrm{~h})$, solution temperature (30$60^{\circ} \mathrm{C}$ ) and solution $\mathrm{pH}(2-12)$. Adsorption of methyl red dye was observed to increase with increase in initial dye concentration, contact time and solution temperature. The methyl red dye adsorption uptake and percentage removal at equilibrium showed that the adsorption process is majorly dependent on the initial dye concentration. Optimum percentage of methyl red dye removed was observed at $\mathrm{pH} 2$. The adsorption process of methyl red dye onto LGLAC was endothermic in nature. Thermodynamic parameters, including entropy change $\left(\Delta S^{0}\right)$, enthalpy change $\left(\Delta H^{0}\right)$, and Gibbs free energy change $\left(\Delta \mathrm{G}^{0}\right)$ were evaluated. The adsorption process was endothermic and the mechanism followed a physisorption process.
\end{abstract}

(C) 2019 Published by Elsevier B.V.

\footnotetext{
* Corresponding author at: Department of Pure and Applied Chemistry, Ladoke Akintola University of Technology P.M.B 4000, Ogbomoso, Oyo State, Nigeria.

E-mail address: osbello@lautech.edu.ng (O.S. Bello).
} 
Specifications table

\begin{tabular}{ll}
\hline Subject area & Physical Chemistry, Chemical Engineering \\
Compounds & Methylred (MR), Lemongrass, Sodium hydroxide $(\mathrm{NaOH})$ \\
Data category & Spectra, graphs, images, preparation and activation procedures \\
Data acquisition format & Elemental analyzer, FTIR, TGA analyzer, SEM, MR dye adsorption data \\
Data type & The data analyzed \\
Procedure & Data obtained from characterization of LGchar and LGLAC via TGA \\
& SEM, FTIR and other physico-chemical techniques. \\
& Adsorption studies: \\
& - Initial dye concentration from $25-500 \mathrm{mg} / \mathrm{L}$. \\
& - pH was varied between 2 and 12. \\
& - Solution temperature ranges from $30-60{ }^{\circ} \mathrm{C}$ \\
& - Contact time ranges from $0-24 \mathrm{~h}$. \\
Data accessibility & All data are available with this article. \\
\hline
\end{tabular}

\section{Rationale}

Industrial utilization of dyes in the past decades has increased drastically thereby increasing the challenges pose on the ecosystem thereby threatening the global peace. Many industries including paper, textile, printing, leather, plastics and food industries use dyes in their diverse applications [1-8]. However, compounds that contained dyes are toxic to animals and humans' life even at a low concentration. Their effects are teratogenic, carcinogenic, and mutagenic, which consequently results in adverse health conditions to the human and animals [4,9-11]. Since last decades, many conventional techniques have been employed to decontaminate dyes from aqueous solution. Examples are chemical, biological and physiochemical methods [12-25]. Dyes are known to be resistant to biological degradation methods and their removal by conventional physicochemical techniques are inefficient [4,26-28]. Thus, economic methods for dye removal from effluents remains a problem for textile industries $[12,29,30]$ thus paving ways for adsorption due to its ability to meet economical demands [4,31-33]. Recently, adsorption techniques are gaining more attentions due to their simplicity in design, cost effectiveness, efficiency, ease of operation, tolerance to toxic materials, biodegradability and capability for treating dyes at high concentrations [3,34-42]. This is a greener approach to cleaning the environment [42-46].

Activated carbon $(A C)$ remains a popular adsorbent having numerous potentials for dye removal from wastewater but the cost of purchasing commercial activated carbon (CAC) limited its uses in the past years [47-50]. As a result of this high cost, scientists all over the globe are searching for suitable alternatives to CAC, such as agricultural materials due to their high efficiency [4]. Therefore ACs from agricultural origins has been utilized as potential adsorbent for remediating various kinds of dyes. Many authors in past decades have studied the adsorption of various dyes onto numerous agricultural materials which include rice husk [51,52], neem [53,54], rambutan seed [55], durian seed [56,57], watermelon rinds [58], lime peel [59], Okra [60], banana stalk [61] mango [62], walnut shells [63,64], cocoa husk [44], orange peel [65-67], Prunus dulcis $[68,69]$, berry leaves [70], de-oiled soya [71] bagasse fly ash [72] and Moringa oleifera leaf and pod [73,74].

Methyl red (MR) is a monoazo dye, one of the toxic, mutagenic or carcinogenic pollutants in water. Its discharges into the receiving bodies and affects both aquatic and human lives [57,75,76]. It causes eyes and skins sensitization, pharyngeal, irritations to digestive tract when swallowed [57,75-77] and/or inhaled [77-80]. Recently, researches into developing low cost alternatively means to reduce or completely remove MR dye have been given more attentions due to their carcinogenic nature when discharged into the water body [79-81]. Herein, we report on the utilization of lemon grass (a readily available, no/low cost material) for the efficient removal of MR dye from aqueous systems.

\section{Procedure}

\subsection{Preparation of adsorbents}

Lemongrass leaves (Cymbopogon citratus) were chosen as precursors for the preparation of ACs. These materials were obtained in the area of Parit Buntar, Perak, Malaysia $\left(5.1474^{\circ} \mathrm{N}, 100.4212^{\circ} \mathrm{E}\right.$ ). Lemongrass leaves were dried at $105{ }^{\circ} \mathrm{C}$ for $24 \mathrm{~h}$ for removal of the moisture contents. The pre-treated material was then carbonized at $700{ }^{\circ} \mathrm{C}$ under nitrogen atmosphere for $1 \mathrm{~h}$ (first pyrolysis). The certain amount of the char produced was then soaked in sodium hydroxide solution $(\mathrm{NaOH})$ at impregnation ratio of $1: 1(\mathrm{NaOH}$ pellets:char $)(\mathrm{g} / \mathrm{g})$. The mixture was stirred and dehydrated in the oven at $100{ }^{\circ} \mathrm{C}$ overnight. Thereafter, the impregnated samples were loaded into a stainless steel vertical tubular reactor placed in a tube furnace for the second pyrolysis. Pyrolysis was carried out to a final temperature of $800{ }^{\circ} \mathrm{C}$ under nitrogen (99.99\%) flow at $150 \mathrm{~cm}^{3} / \mathrm{min}$ and activated for $2 \mathrm{~h}$. Once the desired activation temperature was reached, $\mathrm{N}_{2}$ gas flow was switched to $\mathrm{CO}_{2}$ at flow rate of $150 \mathrm{~cm}^{3} / \mathrm{min}$ to complete of the activation process in $2 \mathrm{~h}$. The activated products were allowed to cool to room temperature, under $\mathrm{N}_{2}$ flow and then washed with hot de-ionized water followed by hydrochloric acid $(\mathrm{HCl})$ until the solution $\mathrm{pH}$ reached 6.5 - 7.0. Finally, the samples were dried at $100{ }^{\circ} \mathrm{C}$ and kept in an airtight container for adsorption study. 
Table 1

Properties of MR .

\begin{tabular}{ll}
\hline Dye name & Methyl red \\
\hline Molecular formula & $\mathrm{C}_{15} \mathrm{H}_{15} \mathrm{~N}_{3} \mathrm{O}_{2}$ \\
Molecular weight, g/mol & 269.3 \\
CAS no. & $493-52-7$ \\
$\lambda$ max.(nm) & 520 \\
Chemical structure &
\end{tabular}

Table 2

Adsorption isotherm and kinetics.

\begin{tabular}{|c|c|c|c|}
\hline Adsorption model & Type & Expression & Refs. \\
\hline \multirow[t]{10}{*}{ Isotherm } & Langmuir & $\begin{array}{l}\frac{C_{e}}{q_{e}}=\frac{1}{q_{m} C_{e}}+\frac{1}{\mathrm{~K}_{\mathrm{L}} q_{m}} \\
R_{L}=\left[\frac{1}{\left(1+\mathrm{K}_{\mathrm{L}} \mathrm{Co}\right)}\right]\end{array}$ & {$[93]$} \\
\hline & Freundlich & $\ln q_{e}=\frac{1}{n} \ln C_{e}+\ln K_{f}$ & {$[94]$} \\
\hline & Temkin & $q_{e}=B \ln K_{T}+B \ln C_{e}$ & [95] \\
\hline & Dubinin- & $\ln q_{e}=\ln q_{m}+\beta \varepsilon^{2}$ & {$[96]$} \\
\hline & Radushkevich & $\varepsilon=\mathrm{RT}\left[1+\frac{1}{C_{e}}\right]$ & \\
\hline & & $E=\frac{1}{\sqrt{2 \beta}}$ & {$[97,98]$} \\
\hline & Koble-Corrigan & $q_{e}=\frac{a c_{e}^{n}}{1+b c_{e}^{n}}$ & {$[99]$} \\
\hline & Vieth-Sladek & $q_{e}=k_{v s} C_{e}+\frac{Q_{m} \beta_{v s} C_{e}}{1+\beta_{v s} C_{e}}$ & {$[100]$} \\
\hline & Radke-Prausnitz & $q_{e}=\frac{q_{m R P} K_{R P} C_{e}}{1+K_{R P} C_{e}^{m P P}}$ & {$[101]$} \\
\hline & Brouers-Sotolongo & $q_{e}=Q_{m}\left(1-e^{-k_{B S} C_{e}^{\alpha}}\right)$ & {$[102]$} \\
\hline \multirow[t]{7}{*}{ Kinetics } & Pseudo-first-order & $\ln \left(q_{e}-q_{t}\right)=\ln q_{e}-K_{1}$ & {$[103]$} \\
\hline & Pseudo-second order & $\frac{\mathrm{t}}{\mathrm{q}_{\mathrm{e}}}=\frac{1}{\mathrm{~K}_{2} \mathrm{q}_{\mathrm{e}}}+\frac{1}{\mathrm{q}_{\mathrm{e}} \mathrm{t}}$ & {$[104]$} \\
\hline & Elovich & $q_{t}=\frac{1}{\beta} \ln (\alpha \beta)+\frac{1}{\beta} \ln t$ & {$[105,106]$} \\
\hline & Avrami & $q_{t}=q_{e}\left(1-e^{-\left(k_{A V} t\right)^{n}}\right)$ & {$[107]$} \\
\hline & & $\ln \left(\ln \left(\frac{q_{e}}{q_{e}+q_{t}}\right)\right)=n \ln k_{A V}+n \ln t$ & \\
\hline & Boyd & $B t=-0.4977-\ln \left(1-\frac{q_{t}}{q_{e}}\right)$ & {$[108]$} \\
\hline & Intra-particle diffusion & $q_{t}+K_{\text {diff }} t^{1 / 2}+C$ & {$[22]$} \\
\hline
\end{tabular}

\subsection{Adsorbate preparation}

Methyl red dye used in this study were supplied by Sigma-Aldrich (M) SDN BHD, Malaysia). To prepare a stock solution of MR dye at a concentration of $500 \mathrm{mg} / \mathrm{L}, 0.5 \mathrm{~g}$ of MR dye powder was dissolved in $1000 \mathrm{~mL}$ of deionized water. Solution of different initial concentrations $(25,50,100,200,400$ and $500 \mathrm{mg} / \mathrm{L})$ were prepared by serial dilution process of initial stock solution into $100 \mathrm{~mL}$ of deionized water. The properties of MR are presented in the Table 1.

\subsection{Adsorbent characterization}

The surface morphology of the Lemongrass leaves char (LGLchar) and Lemongrass leaves activated (LGLAC) was examined using a scanning electron microscope (Quanta 450 FEG, Netherland). The proximate analysis was studied using simultaneous thermal analyzer (TGA) (Perkin Elmer STA 6000, USA). Elemental analysis was carried out using elemental analyzer (EA), (Model Perkin Elmer Series II 2400, USA).The surface characteristics of the samples were characterized using Fourier transform infrared (FT-IR) spectrometer (Shimadzu Model IRPrestige-21 Spectrophotometer). The determination of the samples' surface areas, pore volumes and average pore diameters were carried out using Micromeritics ASAP2020 volumetric adsorption analyzer. The surface areas were measured using Brunauer-Emmett-Teller (BET). The total pore volumes were estimated to be the liquid volume of $\mathrm{N}_{2}$ at a relative pressure of 0.98 [41].

\subsection{Batch adsorption experiment}

The experiment was carried out using batch adsorption process at three different temperatures $(30,45$ and $60 \stackrel{\circ}{ })$. For each temperature six Erlenmeyer flasks were used with different dye concentrations (25, 50, 100, 200, 400 and 500 mg/L). 
Table 3

Surface area and pore characteristics of the prepared activated carbons.

\begin{tabular}{lllll}
\hline Sample & BET surface area $\left(\mathrm{m}^{2} / \mathrm{g}\right)$ & Mesopore surface area $\left(\mathrm{m}^{2} / \mathrm{g}\right)$ & Totalpore volume $\left(\mathrm{cm}^{3} / \mathrm{g}\right)$ & Average pore diameter $(\mathrm{nm})$ \\
\hline LG char & 152.44 & 71.87 & 0.138 & 3.47 \\
LGAC & 836.04 & 598.60 & 0.472 & 3.62 \\
\hline
\end{tabular}

$0.10 \mathrm{~g}$ of the LGLAC was added to a series of Erlenmeyer flasks filled with $100 \mathrm{~mL}$ of dye solution. The Erlenmeyer flasks were sealed and kept in an isothermal water bath shaker at a speed of $120 \mathrm{rpm}$ at a constant temperature of $30^{\circ} \mathrm{C}$ until equilibrium was reached. This was also applied to 45 and $60^{\circ} \mathrm{C}$ solution temperatures. The aqueous samples were then withdrawn at a fixed time interval. The UV/Vis spectrophotometer was employed to measure the concentrations at $520 \mathrm{~nm}$ wavelength. For batch and equilibrium studies, the amount of dye uptake at time $t$ (i.e. $\mathrm{q}_{\mathrm{t}}(\mathrm{mg} / \mathrm{g})$ ) and at equilibrium, qe $(\mathrm{mg} / \mathrm{g})$ ), are determined using Eqs. (1) and (2) while the percentage removal at equilibrium were calculated using Eq. (3)

$$
\begin{aligned}
& q_{t}=\frac{\left(C_{0}-C_{t}\right) V}{W} \\
& q_{e}=\frac{\left(C_{o}-C_{e}\right) V}{W}
\end{aligned}
$$

Percentage of dye removal $(\%)=\frac{\left(C_{e}-C_{t}\right)}{C_{t}} \times 100$

where $C_{t}(m g / L)$ is the liquid-phase concentration of MR dye at time $t, C_{0}(m g / L)$ is the initial solute concentration and $C_{e}$ $(\mathrm{mg} / \mathrm{L})$ is the liquid-phase concentrations of MR dye at equilibrium. $\mathrm{V}$ is the volume (L) of the solution and $\mathrm{W}$ is mass $(\mathrm{g})$ of adsorbent $[36,61]$.

\section{Data, value and validation}

\subsection{Surface area and pore characteristics}

The BET surface and mesopore areas were observed to be $836.04 \mathrm{~m}^{2} / \mathrm{g}$ and $598.604 \mathrm{~m}^{2} / \mathrm{g}$, whereas, the average pore diameter and total pore volume of LGLAC are $3.62 \mathrm{~nm}$ and $0.472 \mathrm{~cm}^{3} / \mathrm{g}$ respectively. The activation process in association with $\mathrm{NaOH}$ and $\mathrm{CO}_{2}$ gasification promoted the mesoporous formations that directly resulted in LGLAC high surface area in comparison with LGchar which has low BET and mesoporous surface areas of 152.44 and $71.87 \mathrm{~m}^{2} / \mathrm{g}$ (Table 3).

\subsection{Surface morphologies}

Fig. 1 ( $a$ and $b$ ) shows the SEM images of LGchar and LGLAC. From Fig. 1(a), the surface and pores of LGchar were rough and not properly developed. However, in Fig. 1(b), several pores are clearly observed, many pores are formed on the LGLAC surface. This is an indication that the activation process using $\mathrm{NaOH}$ have contributed to the widening and formations of pores on the LGLAC surface which could enhance MR dye removal. This is requisite for dye adsorption as reported in the literatures $[35,41,42,63,73,82,83]$

\subsection{Surface chemistry}

The FTIR spectra of LGLAC before and after adsorption of MR dye are shown in Fig. 2. The stretching bands are O-H, (3500-3200 $\left.\mathrm{cm}^{-1}\right), \mathrm{C}-\mathrm{H}$ of alkane $\left(2980-2960 \mathrm{~cm}^{-1}\right), \mathrm{C}=\mathrm{O}\left(1700 \mathrm{~cm}^{-1}\right), \mathrm{CH}_{3}\left(1385-1380 \mathrm{~cm}^{-1}\right)$, Aliphatic $\mathrm{C}=\mathrm{C}(1675-$ $\left.1600 \mathrm{~cm}^{-1}\right), \mathrm{N}-\mathrm{O}$ asymmetry $\left(1600-1500 \mathrm{~cm}^{-1}\right), \mathrm{C}-\mathrm{O}\left(1050 \mathrm{~cm}^{-1}\right)$ and $\mathrm{C}-\mathrm{N}\left(1340-1250 \mathrm{~cm}^{-1}\right)$, bending bands are C-H $\left(1470-1430 \mathrm{~cm}^{-1}\right)$ and $\mathrm{O}-\mathrm{H}$ from carboxylic acid $\left(1350-1260 \mathrm{~cm}^{-1}\right)$. However, majority of the functional groups were affected after adsorption of MR dye (Fig. 2b) resulting into bands disappearance, reductions or shifting to lower wavelengths (Fig. 2b). This indicates involvement of these functional groups for binding MR dye to LGLAC $[42,44,84]$. The spectrum of the MR dye loaded lemon grass showed similar characteristics as the lemon grass in raw form except for slight changes as indicated by the disappearance, shift and reduction in some bands after adsorption. The FTIR spectrum of the dye loaded adsorbent indicates that the peaks are slightly shifted from their position and the intensity gets altered. These results indicated the involvement of some functional group in the adsorption of dye ions on the surface of the lemon grass through weak electrostatic interaction or Van der Waals forces. This can be considered as further evidence for the interaction between lemon grass and the MR dye ions. Similar observation were reported by other researchers [85-88]. 

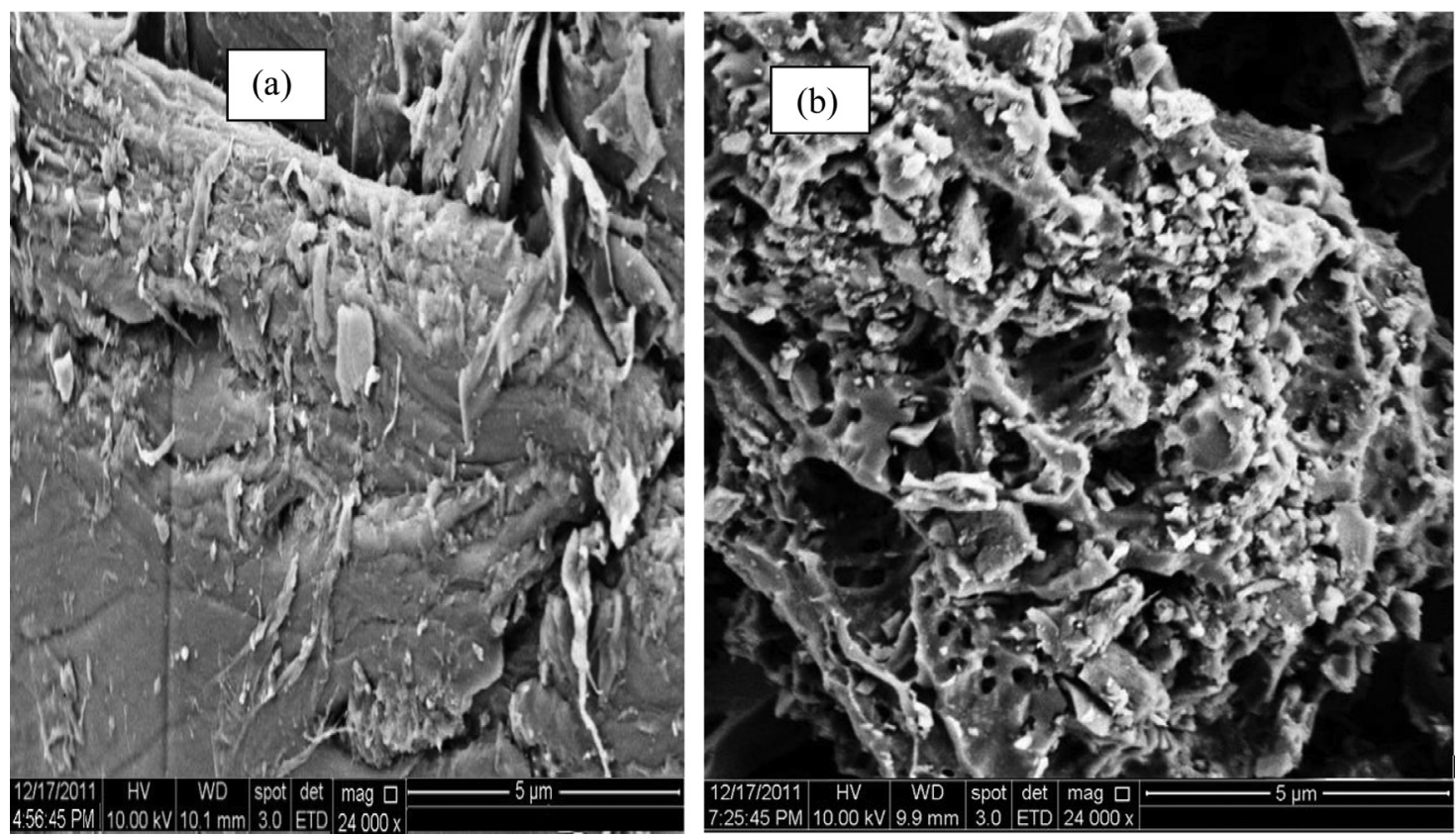

Fig. 1. SEM micrographs of (a) LGLchar and (b) LGLAC (Magnification $=X$ 24000).

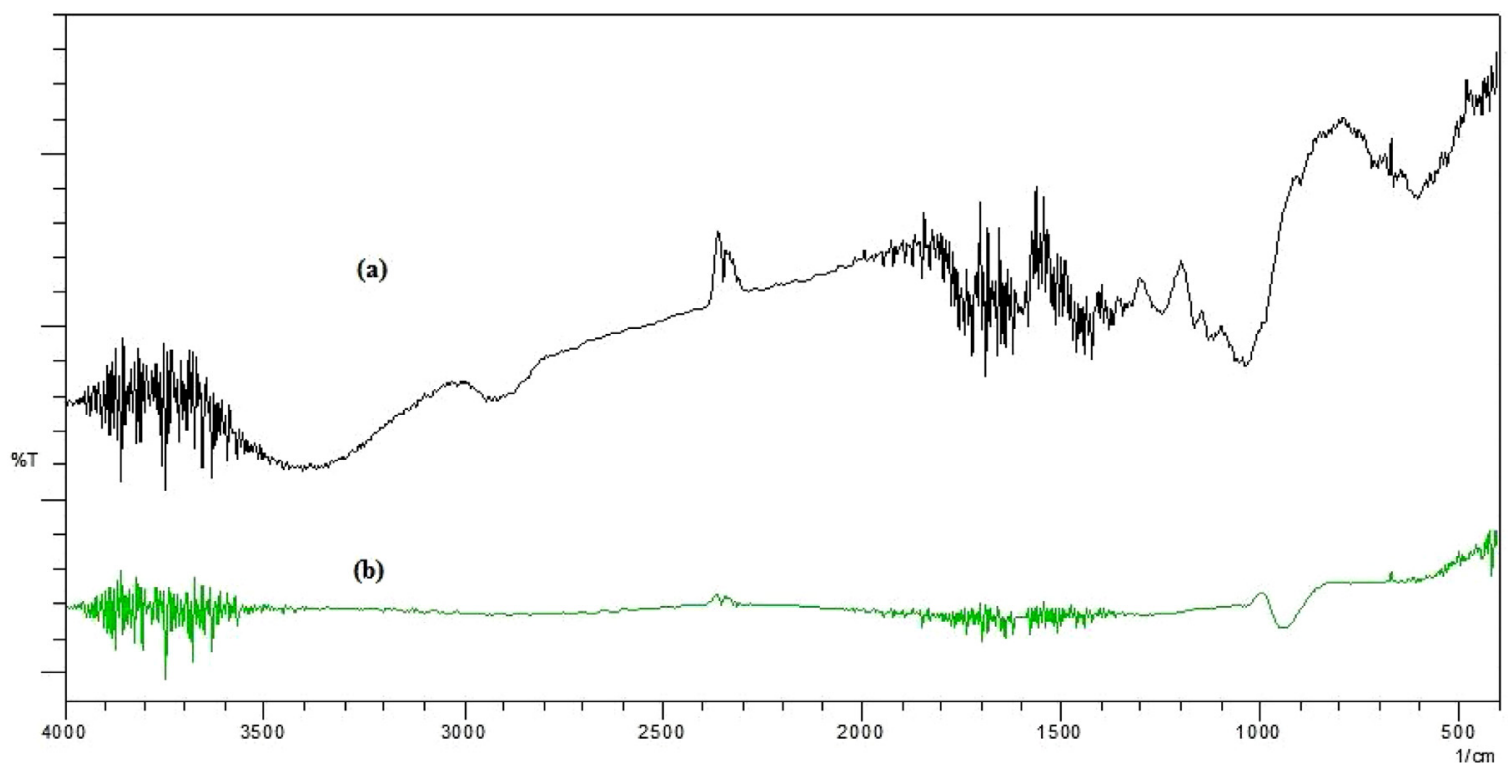

Fig. 2. FT-IR of LGLAC; (a) before adsorption (b) after adsorption.

\subsection{Proximate analysis}

The volatile matter and moisture contents of the raw lemon grass (LGraw) leaf are $67.94 \%$ and $8.80 \%$ respectively. During activation, there was a reduction in moisture content $2.93 \%$ and volatile matter $15.80 \%$ of LGLAC sample. The fixed carbon contents follow the sequence LGAC $(77.41 \%)>$ LGchar $(57.51)>$ LGraw (18.59\%) (Table 4). During carbonization and activation processes at high temperature, the volatile matter is released as gases and liquid products which completely evaporated, leaving only materials with higher carbon contents. A lower ash content of 3.86\% was obtained for LGLAC. In accordance with observations from literature, the lower ash content signifies the applicability of the material as good adsorbent for dye adsorption while higher ash content reduce the performance and efficiency of the adsorbent for dye removal [89-94]. 
Table 4

Proximate content of precursor, char and activated carbon.

\begin{tabular}{lllll}
\hline \multirow{2}{*}{ Sample } & \multicolumn{3}{l}{ Proximate analysis (\%) } \\
\cline { 2 - 5 } & Moisture & Volatile & Fixed carbon & Ash \\
\hline LG raw & 8.80 & 67.94 & 18.59 & 4.67 \\
LG char & 5.13 & 32.86 & 57.51 & 4.50 \\
LGAC & 2.93 & 15.80 & 77.41 & 3.86 \\
\hline
\end{tabular}
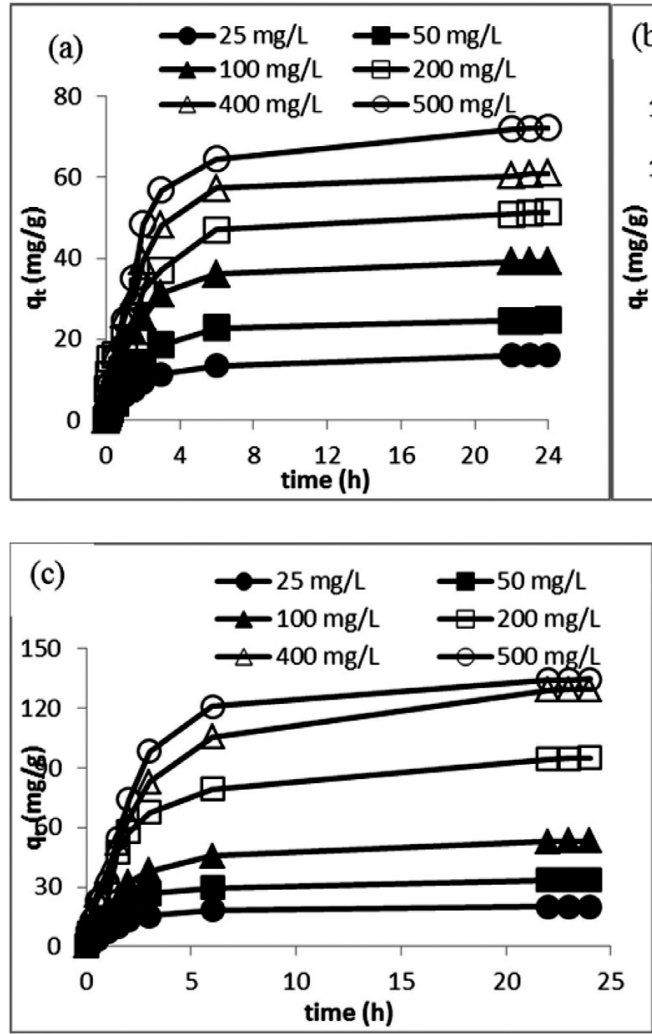
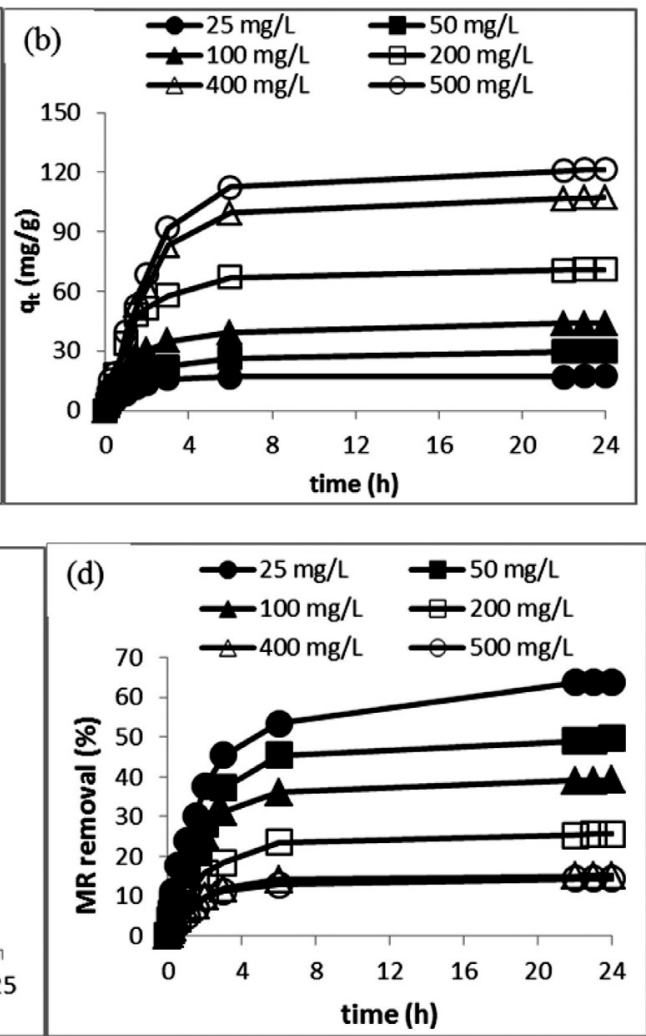

Fig. 3. MR Dye adsorption uptake onto LGLAC at different initial concentrations and contact time at (a) $30^{\circ} \mathrm{C}$, (b) $45^{\circ} \mathrm{C}$, (c) $60^{\circ} \mathrm{C}$, and (d) Percentage removal of MR dye by LGLAC at various initial dye concentration and contact time at $30^{\circ} \mathrm{C}$.

\subsection{Effect of initial MR dye concentration and contact time}

Fig. 3a-c showed the effect of contact time and initial dye concentrations for MR dye uptake onto LGLAC at different temperatures of $30-60^{\circ} \mathrm{C}$. The adsorption of MR dye increased with time. The MR dye uptake were rapid in the early stages of the contact time between $0-5 \mathrm{~h}$, after $5 \mathrm{~h}$, it became very slow until it reached equilibrium in $24 \mathrm{~h}$. This is attributable to larger numbers of vacant sites accessible for MR dye adsorption during the initial stages [95] which decreases with time. Fig. $3 \mathrm{~d}$ shows the percentage removal of MR dye onto the LGLAC at various contact times and different initial dye concentration at $30^{\circ} \mathrm{C}$. A gradual increase of percentage MR dye removal was observed as the initial dye concentration increases (Table 5).

Table 5

Adsorption of dyes uptakes and Percentage of dyes removal at equilibrium.

\begin{tabular}{lll}
\hline Concentration $(\mathrm{mg} / \mathrm{L})$ & MR dyes uptake $(\mathrm{mg} / \mathrm{g})$ & MR dye removal $(\%)$ \\
\hline 25 & 15.97 & 63.87 \\
50 & 24.83 & 49.66 \\
100 & 39.30 & 39.30 \\
200 & 51.32 & 25.66 \\
400 & 60.99 & 15.25 \\
500 & 72.32 & 14.46 \\
\hline
\end{tabular}




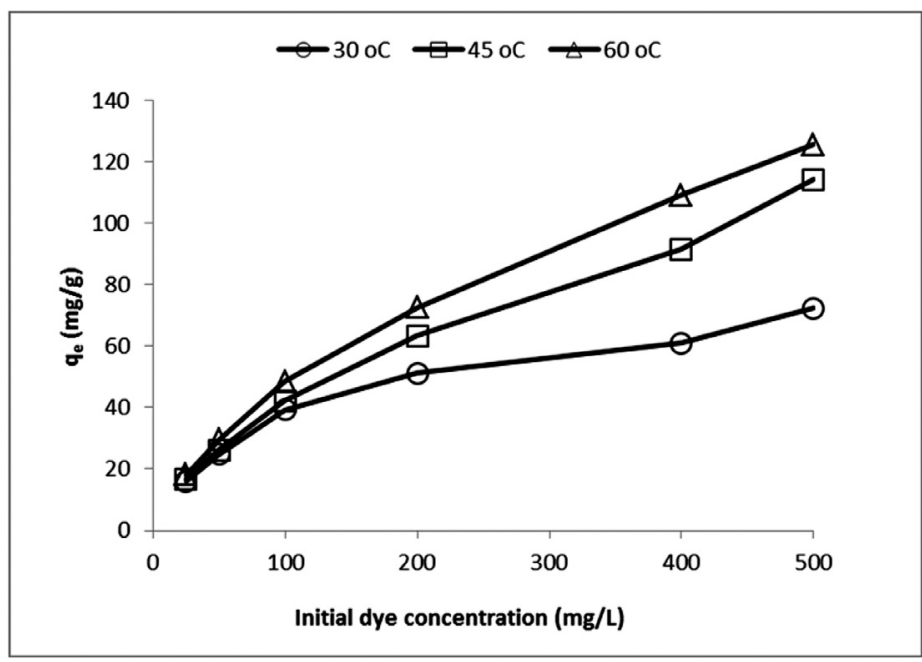

Fig. 4. Effect of solution temperature on the MR dye uptake.

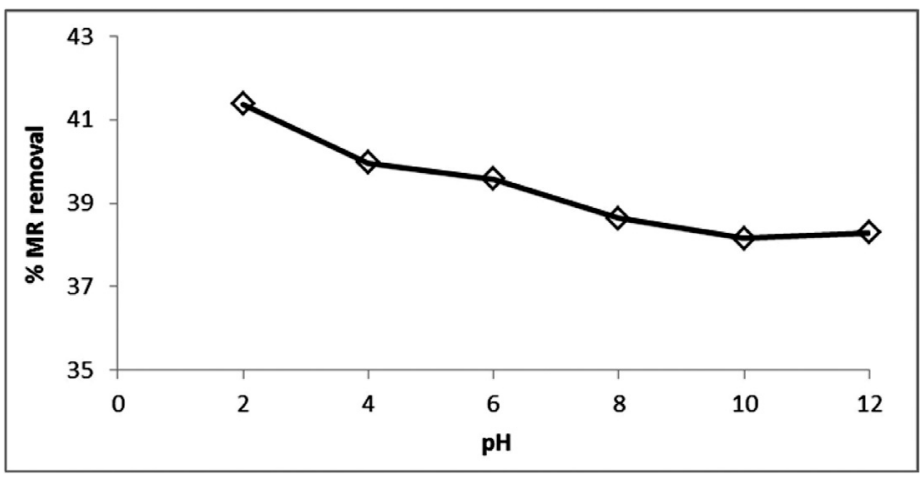

Fig. 5. Effect of initial pH on the MR dye uptake. .

\subsection{Effect of solution temperature}

Fig. 4 presents the influence of solution temperature on the MR dye uptake onto LGLAC. The amount of MR dye uptake, $\mathrm{qe}(\mathrm{mg} / \mathrm{g})$ increased with the increase in solution temperature from $30-60{ }^{\circ} \mathrm{C}$ at all initial dye concentration. This suggests that the adsorption of MR dye onto LGLAC is endothermic in nature. When solution temperature was increased, the chemical interactions between MR dye and the adsorbent's surface functionalities also increased. In other words, there is increase in mobility of MR dye to penetrate deeper into the pores of the LGLAC. In addition, the physical bonding between MR dyes and LGLAC active sites become enhanced [57]. Besides, increasing the solution temperature, the viscosity of MR dye solutions also decreased. Therefore, the diffusion rate of the MR dye molecule across the external boundary layers and in the internal pores of the LGLAC is greatly improved [41,55,96].

\subsection{Effect of solution $\mathrm{pH}$}

Fig. 5 presents the effects of solution pH on the MR dye removal with the optimum percentage removal of $41.38 \%$ for MR dye at $\mathrm{pH}$ 2. This inferred that the LGLAC surfaces would be attracted to the positively charged functional groups on MR dye thereby improving the adsorption capacity. At lower $\mathrm{pH}$ value, more protons will be available to protonate the dye molecule resulting in electrostatic attraction between the positively charged MR dye and negatively charged LGLAC. Increasing the initial $\mathrm{pH}$ of the system, the negatively charged LGLAC sites predominates, thus establishing electrostatic repulsion between the negatively charged surface of the LGLAC and negatively charged MR dye molecule [97].The trend of MR dye adsorption in $\mathrm{pH}$ range 2-12 is shown in Fig. 5. The amount of MR dye adsorbed decreased with increase in initial pH. The optimum $\mathrm{pH}$ value for MR dye was found to be 2. The difference in percentage removal in this $\mathrm{pH}$ range was largely due to the structural changes observed in the MR dye molecules and the surface adsorption characteristics of LGLAC indicating that the adsorption capacities of the adsorbent is $\mathrm{pH}$ dependent [97,98]. It is well known that reactive dyes upon dissolutions release 
Table 6

Isotherm parameters for MR dye adsorption unto LGLAC at $30^{\circ}$

\begin{tabular}{|c|c|c|c|c|c|c|c|}
\hline Langmuir & Freundlich & Temkin & Dubinin-Radushkevich & Koble-Corrigan & Radke-Prausnitz & Vieth-Sladek & Brouers-Sotolongo \\
\hline$q_{\mathrm{m}}=76.923$ & $k_{\mathrm{F}}=7.396$ & $B=14.076$ & $q_{\mathrm{s}}=49.30$ & $A_{\mathrm{kc}}=5.39$ & $q_{\mathrm{m}}=16.254$ & $k_{\mathrm{VS}}=5.9 \times 10^{-2}$ & $q_{\mathrm{m}}=94.254$ \\
\hline$k_{\mathrm{L}}=1.84 \times 10^{-2}$ & $1 / \mathrm{n}_{\mathrm{F}}=0.38$ & $A=0.281$ & $\begin{array}{l}E=158.11 \\
b_{\mathrm{DR}}=2 \times 10^{-5}\end{array}$ & $\begin{array}{l}B_{\mathrm{kc}}=4.2 \times 10^{-2} \\
n=0.55 \\
q_{\mathrm{m}}=342.9\end{array}$ & $\begin{array}{l}k_{\mathrm{RP}}=0.240 \\
m_{\mathrm{RP}}=0.754\end{array}$ & $\begin{array}{l}q_{\mathrm{m}}=47.120 \\
B_{\mathrm{VS}}=4.7 \times 10^{-2}\end{array}$ & $\begin{array}{l}k_{\mathrm{BS}}=6.43 \times 10^{-2} \\
\alpha=0.499\end{array}$ \\
\hline$R^{2}=0.983$ & $R^{2}=0.982$ & $R^{2}=0.978$ & $R^{2}=0.692$ & $R^{2}=0.997$ & $R^{2}=0.987$ & $R^{2}=0.989$ & $R^{2}=0.985$ \\
\hline
\end{tabular}

Table 7

Kinetic model constant parameters for MR dye adsorption unto lemon grass at $30^{\circ} \mathrm{C}$.

\begin{tabular}{|c|c|c|c|c|c|c|c|}
\hline \multirow{2}{*}{ Model } & \multirow{2}{*}{$\begin{array}{l}\text { Kinetic } \\
\text { parameters }\end{array}$} & \multicolumn{6}{|c|}{ Initial MR dye concentration (mg/L) } \\
\hline & & 25 & 50 & 100 & 200 & 400 & 500 \\
\hline \multirow{5}{*}{ Pseudo-first-order } & $\mathrm{Q}_{\mathrm{e}}, \exp \left(\mathrm{mg} \mathrm{g}^{-1}\right)$ & 15.968 & 24.828 & 39.296 & 51.32 & 60.988 & 72.32 \\
\hline & $\mathrm{K}_{1}\left(\min ^{-1}\right)$ & 0.406 & 0.445 & 0.503 & 0.387 & 0.508 & 0.509 \\
\hline & $\mathrm{Q}_{\mathrm{e}}$ cal $\left(\mathrm{mg} \mathrm{g}^{-1}\right)$ & 15.214 & 25.503 & 37.003 & 44.492 & 60.087 & 72.298 \\
\hline & $\mathrm{R}^{2}$ & 0.990 & 0.989 & 0.992 & 0.968 & 0.994 & 0.986 \\
\hline & $\Delta \mathrm{q}_{\mathrm{e}}(\%)$ & 4.722 & 2.719 & 5.835 & 13.305 & 1.477 & 0.030 \\
\hline \multirow{4}{*}{$\begin{array}{l}\text { Pseudo-second- } \\
\text { order }\end{array}$} & $\mathrm{K}_{2}\left(\min ^{-1}\right)$ & 0.0344 & 0.0070 & 0.0170 & 0.0194 & 0.0058 & 0.0067 \\
\hline & $\mathrm{Q}_{\mathrm{e}}$ cal $\left(\mathrm{mg} \mathrm{g}^{-1}\right)$ & 17.182 & 38.023 & 43.860 & 51.814 & 79.365 & 84.034 \\
\hline & $\mathrm{R}^{2}$ & 0.976 & 0.964 & 0.988 & 0.951 & 0.983 & 0.948 \\
\hline & $\Delta \mathrm{q}_{\mathrm{e}}(\%)$ & 7.603 & 53.146 & 11.614 & 0.963 & 30.132 & 16.198 \\
\hline \multirow[t]{3}{*}{ Elovich } & $\alpha\left(\mathrm{mg} \mathrm{g}^{-1} \min ^{-1}\right)$ & 3.822 & 1.751 & 2.211 & 2.591 & 1.022 & 0.862 \\
\hline & $\beta\left(\mathrm{g} \mathrm{mg}^{-1}\right)$ & 2.915 & 4.809 & 6.965 & 8.327 & 11.417 & 13.36 \\
\hline & $\mathrm{R}^{2}$ & 0.982 & 0.952 & 0.696 & 0.962 & 0.961 & 0.947 \\
\hline \multicolumn{8}{|l|}{ Avrami } \\
\hline & $\mathrm{k}_{\mathrm{AV}}\left(\min ^{-1}\right)$ & 0.0051 & 0.0041 & 0.0062 & 0.0070 & 0.0054 & 0.0053 \\
\hline & $\mathrm{n}_{\mathrm{AV}}$ & 0.718 & 0.782 & 0.646 & 0.532 & 0.736 & 0.674 \\
\hline & $\mathrm{R}^{2}$ & 0.879 & 0.894 & 0.857 & 0.834 & 0.866 & 0.872 \\
\hline
\end{tabular}

Table 8

Intraparticle diffusion model parameters for MR dye adsorption on LGLAC at $30^{\circ} \mathrm{C}$.

\begin{tabular}{|c|c|c|c|c|c|c|c|c|c|}
\hline \multirow[b]{2}{*}{ Initial MR dye conc. (mg/L) } & \multicolumn{3}{|c|}{$\left(\mathrm{mg} / \mathrm{g} \mathrm{h}^{1 / 2}\right)$} & \multirow[b]{2}{*}{$\mathrm{C}_{1}$} & \multirow[b]{2}{*}{$\mathrm{C}_{2}$} & \multirow[b]{2}{*}{$\mathrm{C}_{3}$} & \multirow[b]{2}{*}{$\left(\mathrm{R}_{1}\right)^{2}$} & \multirow[b]{2}{*}{$\left(\mathrm{R}_{2}\right)^{2}$} & \multirow[b]{2}{*}{$\left(\mathrm{R}_{3}\right)^{2}$} \\
\hline & $\mathrm{k}_{\mathrm{p} 1}$ & $\mathrm{k}_{\mathrm{p} 2}$ & $\mathrm{k}_{\mathrm{p} 3}$ & & & & & & \\
\hline 25 & 3.019 & 6.025 & 3.218 & 0 & -0.102 & 56.664 & 1 & 0.958 & 0.999 \\
\hline 50 & 2.754 & 11.105 & 1.499 & 0 & -2.846 & 53.565 & 1 & 0.975 & 0.996 \\
\hline 100 & 8.16 & 15.52 & 1.729 & 0 & 1.391 & 42.846 & 1 & 0.961 & 0.998 \\
\hline 200 & 27.816 & 17.874 & 1.306 & 0 & 4.417 & 32.901 & 1 & 0.983 & 0.997 \\
\hline 400 & 8.32 & 26.565 & 0.836 & 0 & -2.333 & 20.615 & 1 & 0.964 & 0.993 \\
\hline 500 & 21.655 & 30.972 & 1.096 & 0 & -3.67 & 10.69 & 1 & 0.941 & 0.996 \\
\hline
\end{tabular}

Table 9

Thermodynamic parameters for adsorption of MR dyes on LGLAC.

\begin{tabular}{lllllll}
\hline Dye & $\Delta \mathrm{H}^{\circ}(\mathrm{kJ} / \mathrm{mol})$ & $\Delta \mathrm{S}^{\circ}(\mathrm{J} / \mathrm{mol} . \mathrm{K})$ & $\mathrm{E}_{\mathrm{a}}(\mathrm{kJ} / \mathrm{mol} . \mathrm{K})$ & & $-\Delta \mathrm{G}^{\circ}(\mathrm{kJ} / \mathrm{mol})$ & \\
\cline { 3 - 6 } & & & & $303 \mathrm{~K}$ & $318 \mathrm{~K}$ & $333 \mathrm{~K}$ \\
\hline MR & 18.221 & 20.383 & 11.025 & 12.045 & 11.739 & 11.434 \\
\hline
\end{tabular}

colored dye anions into solutions. The adsorption of these charged dye groups onto an adsorbed surface is influenced by the surface charge on the adsorbent [97].

\subsection{Isotherm, kinetic and thermodynamic studies}

Table 6 shows the isotherm parameters for MR dye adsorption unto LGLAC at $30^{\circ} \mathrm{C}$ while Table 7 presents the kinetic model constant parameters for MR dye adsorption unto lemon grass at $30^{\circ} \mathrm{C}$. The Intraparticle diffusion model parameters for MR dye adsorption on LGLAC at $30^{\circ} \mathrm{C}$ are reported in Table 8 . The adsorption process was found to be endothermic $(\Delta \mathrm{H}$ is positive) and spontaneous ( $\Delta \mathrm{G}$ is negative) in nature as shown in Table 9.

\section{Conclusion}

LGL was successfully used as precursor to produce ACs for the removal MRdye by physiochemical activation method. Batch adsorption was studied using different parameters. The percentage dye removal for MR dyes decreased as the initial 
dye concentration increase. Adsorption of MR dye was found to increase with increase in initial MR dye concentrations, contact time, and solution temperatures.

\section{Acknowledgments}

Supports obtained from "Bridging Grant from Universiti Sains Malaysia" (first and second author), NRF-TWAS Doctoral scholarship award (UID: 105453 \& Reference: SFH160618172220) (the third author) and LAUTECH 2016 TET Fund Institution Based Research Intervention (TETFUND/DESS/UNI/OGBOMOSO/RP/VOL. IX) given to the corresponding author are all acknowledged.

\section{Supplementary materials}

Supplementary material associated with this article can be found, in the online version, at doi:10.1016/j.cdc.2019.100249.

\section{References}

[1] M. Rafatullah, O. Sulaiman, R. Hashim, A. Ahmad, Adsorption of methylene blue on low-cost adsorbents: a review, J. Hazard. Mater. 177 (2010) $70-80$, doi:10.1016/j.jhazmat.2009.12.047.

[2] M. Shahadat, M. Rafatullah, T.T. Teng, Characterization and sorption behavior of natural adsorbent for exclusion of chromium ions from industrial effluents, Desalin. Water Treat. 53 (2015) 1395-1403, doi:10.1080/19443994.2013.855678.

[3] O.S. Bello, K.A. Adegoke, A.A. Olaniyan, H. Abdulazeez, Dye adsorption using biomass wastes and natural adsorbents: overview and future prospects, Desalin. Water Treat. 53 (2015) 1292-1315, doi:10.1080/19443994.2013.862028.

[4] K.A. Adegoke, O.S. Bello, Dye sequestration using agricultural wastes as adsorbents, Water Resour. Ind. 12 (2015) 8-24, doi:10.1016/j.wri.2015.09.002.

[5] L. Ding, B. Zou, W. Gao, Q. Liu, Z. Wang, Y. Guo, X. Wang, Y. Liu, Adsorption of Rhodamine-B from aqueous solution using treated rice husk-based activated carbon, Colloids Surfaces A Physicochem. Eng. Asp. 446 (2014) 1-7, doi:10.1016/j.colsurfa.2014.01.030.

[6] A.A. Inyinbor, F.A. Adekola, G.A. Olatunji, Adsorption of Rhodamine B dye from aqueous solution on Irvingia gabonensis biomass: kinetics and thermodynamics studies, South African J. Chem. 68 (2015) 115-125, doi:10.17159/0379-4350/2015/v68a17.

[7] M. Ahmaruzzaman, V.K. Gupta, Rice husk and its ash as low-cost adsorbents in water and wastewater treatment, Ind. Eng. Chem. Res. 50 (2011) 13589-13613, doi:10.1021/ie201477c.

[8] V.K. Gupta, A. Nayak, S. Agarwal, I. Tyagi, Potential of activated carbon from waste rubber tire for the adsorption of phenolics: effect of pre-treatment conditions, J. Colloid Interface Sci. 417 (2014) 420-430, doi:10.1016/j.jcis.2013.11.067.

[9] P. Wang, Q. Ma, D. Hu, L. Wang, Adsorption of methylene blue by a low-cost biosorbent: citric acid modified peanut shell, Desalin. Water Treat 57 (2016) 10261-10269, doi:10.1080/19443994.2015.1033651.

[10] D.K. Mahmoud, M.A.M. Salleh, W.A.W.A. Karim, A. Idris, Z.Z. Abidin, Batch adsorption of basic dye using acid treated kenaf fibre char: equilibrium, kinetic and thermodynamic studies, Chem. Eng. J. 181-182 (2012) 449-457, doi:10.1016/j.cej.2011.11.116.

[11] A.A. Adeyemo, I.O. Adeoye, O.S. Bello, Adsorption of dyes using different types of clay: a review, Appl. Water Sci. 7 (2017) 543-568, doi:10.1007) s13201-015-0322-y.

[12] T.A. Saleh, V.K. Gupta, Functionalization of tungsten oxide into MWCNT and its application for sunlight-induced degradation of Rhodamine B, J. Colloid Interface Sci. 362 (2011) 337-344, doi:10.1016/j.jcis.2011.06.081.

[13] R. Saravanan, N. Karthikeyan, V.K. Gupta, E. Thirumal, P. Thangadurai, V. Narayanan, A. Stephen, ZnO/Ag nanocomposite, An efficient catalyst for degradation studies of textile effluents under visible light, Mater. Sci. Eng. C. 33 (2013) 2235-2244, doi:10.1016/j.msec.2013.01.046.

[14] L. Laasri, M.K. Elamrani, O. Cherkaoui, Removal of two cationic dyes from a textile effluent by filtration-adsorption on wood sawdust, Environ. Sci. Pollut. Res. 14 (2007) 237-240, doi:10.1065/espr2006.08.331

[15] M. Ghaedi, S. Hajjati, Z. Mahmudi, I. Tyagi, S. Agarwal, A. Maity, V.K. Gupta, Modeling of competitive ultrasonic assisted removal of the dyes Methylene blue and Safranin-O using Fe304 nanoparticles, Chem. Eng. J. 268 (2015) 28-37, doi:10.1016/j.cej.2014.12.090.

[16] R. Saravanan, M. Mansoob Khan, V.K. Gupta, E. Mosquera, F. Gracia, V. Narayanan, A. Stephen, ZnO/Ag/CdO nanocomposite for visible light-induced photocatalytic degradation of industrial textile effluents, J. Colloid Interface Sci. 452 (2015) 126-133, doi:10.1016/j.jcis.2015.04.035.

[17] R. Saravanan, V.K. Gupta, V. Narayanan, A. Stephen, Visible light degradation of textile effluent using novel catalyst ZnO/ $\gamma$-Mn203, J. Taiwan Inst. Chem. Eng. 45 (2014) 1910-1917, doi:10.1016/j.jtice.2013.12.021.

[18] R. Saravanan, S. Joicy, V.K. Gupta, V. Narayanan, A. Stephen, Visible light induced degradation of methylene blue using CeO 2/V2O5 and CeO2/CuO catalysts, Mater. Sci. Eng. C. 33 (2013) 4725-4731, doi:10.1016/j.msec.2013.07.034.

[19] K.A. Adegoke, R.O. Oyewole, B.M. Lasisi, O.S. Bello, Abatement of organic pollutants using fly ash based adsorbents, Water Sci. Technol. 76 (2017) 2580-2592, doi:10.2166/wst.2017.437.

[20] S.D. Khattri, M.K. Singh, Removal of malachite green from dye wastewater using neem sawdust by adsorption, J. Hazard. Mater. 167 (2009) 1089-1094, doi:10.1016/j.jhazmat.2009.01.101.

[21] H. Singh, G. Chauhan, A.K. Jain, S.K. Sharma, Adsorptive potential of agricultural wastes for removal of dyes from aqueous solutions, J. Environ. Chem. Eng. 5 (2017) 122-135, doi:10.1016/j.jece.2016.11.030

[22] I.M. Banat, P. Nigam, D. Singh, R. Marchant, Microbial decolorization of textile-dye-containing effluents: a review, Bioresour. Technol. 58 (1996) $217-$ 227, doi:10.1016/S0960-8524(96)00113-7.

[23] S. Dawood, T.K. Sen, Review on dye removal from its aqueous solution into alternative cost effective and non-conventional adsorbents, Chem. Process Eng. 1 (2014) 1-7, doi:10.1074/jbc.M111.237966.

[24] M.B. Kasiri, N. Modirshahla, H. Mansouri, Decolorization of organic dye solution by ozonation; optimization with response surface methodology, Int. J. Ind. Chem. 4 (2013) 3-10, doi:10.1186/2228-5547-4-3.

[25] A. Simi, V. Azeeza, Removal of methylene blue dye using low cost adsorbent, Asian J. Chem. 4 (2010) 91-102.

[26] O.S. Bello, I.O. Lateef, O.U. Bello, Adsorption characteristics of mango leaf(mangifera indica) powder as adsorbent for malachite green dye removal from aqueous solution, Covenant J. Phys. Life Sci. 2 (2014) 1-13.

[27] O.S. Bello, O.A. Olusegun, V.O. Njoku, Fly ash: an alternative to powdered activated carbon for the removal of eosin dye from aqueous solutions, Bull. Chem. Soc. Ethiop 272 (2013) 191-204, doi:10.4314/bcse.v27i2.4.

[28] O.S. Bello, I.A. Adeogun, J.C. Ajaelu, E.O. Fehintola, Adsorption of methylene blue onto activated carbon derived from periwinkle shells: kinetics and equilibrium studies, Chem. Ecol. 24 (2008) 285-295, doi:10.1080/02757540802238341.

[29] R. Saravanan, V.K. Gupta, V. Narayanan, A. Stephen, Comparative study on photocatalytic activity of ZnO prepared by different methods, J. Mol. Liq. 181 (2013) 133-141, doi:10.1016/j.molliq.2013.02.023.

[30] R. Saravanan, V.K. Gupta, E. Mosquera, F. Gracia, Preparation and characterization of V2O5/ZnO nanocomposite system for photocatalytic application, J. Mol. Liq. 198 (2014) 409-412, doi:10.1016/j.molliq.2014.07.030.

[31] C.N.R. Amaral, F.N. Feiteira, R.C. Cruz, V.O. Cravo, R.J. Cassella, W.F. Pacheco, Removal of basic violet 3 dye from aqueous media using a steel industry residue as solid phase, J. Environ. Chem. Eng. 4 (2016) 4184-4193, doi:10.1016/j.jece.2016.09.023. 
[32] G. Kanadasan, M.D. Mashitah, V.M. Vadivelu, Fixed bed adsorption of methylene blue by using palm oil mill effluent waste activated sludge, in: 3rd IWA Asia Pacific Young Water Prof. Conf., 2010, pp. 1-8. http://eprints.usm.my/20368.

[33] L. Bulgariu, L.B. Escudero, O.S. Bello, M. Iqbal, J. Nisar, K.A. Adegoke, F. Alakhras, M. Kornaros, I. Anastopoulos, The utilization of leaf-based adsorbents for dyes removal: a review, J. Mol. Liq. 276 (2019) 728-747, doi:10.1016/J.MOLLIO.2018.12.001.

[34] O.S. Bello, E.S. Owojuyigbe, M.A. Babatunde, F.E. Folaranmi, Sustainable conversion of agro-wastes into useful adsorbents, Appl. Water Sci. 7 (2017) 3561-3571, doi:10.1007/s13201-016-0494-0.

[35] O.S. Bello, M.A. Ahmad, Adsorptive removal of a synthetic textile dye using cocoa pod husks, Toxicol. Environ. Chem. 93 (2011) 1298-1308, doi:10. 1080/02772248.2011.590490.

[36] O.S. Bello, M.A. Ahmad, Removal of Remazol brilliant Violet-5R dye using periwinkle shells, Chem. Ecol. 27 (2011) 481-492, doi:10.1080/02757540. 2011.600696

[37] S. Wong, N. Ngadi, I.M. Inuwa, O. Hassan, P. Wang, Q. Ma, D. Hu, L. Wang, S.S. Imam, P. Panneerselvam, L. Zhang, Z. Cheng, X. Guo, X. Jiang, T. Li, H.P. Boehm, O.S. Bello, T.A. Fatona, F.S. Falaye, O.M. Osuolale, V.O. Njoku, A. Kishor, S. A.K, C. A.S, S. Boumchita, A. Lahrichi, Y. Benjelloun, S. Lairini, V. Nenov, F. Zerrouq, Q. Zhang, X. Kong, X. Jia, X. Ren, Application of peanut shell as a low-cost adsorbent for the removal of anionic dye from aqueous solutions, J. Clean. Prod. 8 (2012) 5-7, doi:10.1089/ees.2010.0385.

[38] V.K. Gupta, M.R. Ganjali, A. Nayak, B. Bhushan, S. Agarwal, Enhanced heavy metals removal and recovery by mesoporous adsorbent prepared from waste rubber tire, Chem. Eng. J. 197 (2012) 330-342, doi:10.1016/j.cej.2012.04.104.

[39] N. Gupta, A.K. Kushwaha, M.C. Chattopadhyaya, Application of potato (Solanum tuberosum) plant wastes for the removal of methylene blue and malachite green dye from aqueous solution, Arab. J. Chem. 9 (2016) S707-S716, doi:10.1016/j.arabjc.2011.07.021

[40] M.A. Islam, M.J. Ahmed, W.A. Khanday, M. Asif, B.H. Hameed, Mesoporous activated coconut shell-derived hydrochar prepared via hydrothermal carbonization-NaOH activation for methylene blue adsorption, J. Environ. Manage. 203 (2017) 237-244, doi:10.1016/j.jenvman.2017.07.029.

[41] M.A. Ahmad, R. Alrozi, Removal of malachite green dye from aqueous solution using rambutan peel-based activated carbon: equilibrium, kinetic and thermodynamic studies, Chem. Eng. J. 171 (2011) 510-516, doi:10.1016/j.cej.2011.04.018.

[42] M.A. Ahmad, N.S. Afandi, K.A. Adegoke, O.S. Bello, Optimization and batch studies on adsorption of malachite green dye using rambutan seed activated carbon, Desalin. Water Treat. 57 (2016) 21487-21511, doi:10.1080/19443994.2015.1119744.

[43] J. Gao, Y. Qin, T. Zhou, D. Cao, P. Xu, D. Hochstetter, Y. Wang, Adsorption of methylene blue onto activated carbon produced from tea (Camellia sinensis L.) seed shells: kinetics, equilibrium, and thermodynamics studies, J. Zhejiang Univ. Sci. B. 14 (2013) 650-658, doi:10.1631/jzus.B12a0225.

[44] M.O. Olakunle, A.A. Inyinbor, A.O. Dada, O.S. Bello, Combating dye pollution using cocoa pod husks: a sustainable approach, Int. J. Sustain. Eng. 11 (2018) 4-15, doi:10.1080/19397038.2017.1393023.

[45] O.S. Bello, T.A. Fatona, F.S. Falaye, O.M. Osuolale, V.O. Njoku, Adsorption of eosin dye from aqueous solution using groundnut hull-based activated carbon: kinetic, equilibrium, and thermodynamic studies, Environ. Eng. Sci. 29 (2011) 186-194, doi:10.1089/ees.2010.0385.

[46] N. Mohammadi, H. Khani, V.K. Gupta, E. Amereh, S. Agarwal, Adsorption process of methyl orange dye onto mesoporous carbon material-kinetic and thermodynamic studies, J. Colloid Interface Sci. 362 (2011) 457-462, doi:10.1016/j.jcis.2011.06.067.

[47] V.K. Gupta, D. Pathania, S. Sharma, S. Agarwal, P. Singh, Remediation and recovery of methyl orange from aqueous solution onto acrylic acid grafted Ficus carica fiber: isotherms, kinetics and thermodynamics, J. Mol. Liq. 177 (2013) 325-334, doi:10.1016/j.molliq.2012.10.007.

[48] V.K. Gupta, T.A. Saleh, Sorption of pollutants by porous carbon, carbon nanotubes and fullerene-an overview, Environ. Sci. Pollut. Res. 20 (2013) 2828-2843, doi:10.1007/s11356-013-1524-1.

[49] A. Asfaram, M. Ghaedi, S. Agarwal, I. Tyagi, V.K. Gupta, Removal of basic dye Auramine-O by zns:Cu nanoparticles loaded on activated carbon: optimization of parameters using response surface methodology with central composite design, RSC Adv 5 (2015) 18438-18450, doi:10.1039/c4ra15637d.

[50] V.K. Gupta, A. Nayak, S. Agarwal, Bioadsorbents for remediation of heavy metals: current status and their future prospects, Environ. Eng. Res. 20 (2015) 1-18, doi:10.4491/eer.2015.018.

[51] G.G. Mokone, M. Kebaetse, J. Wright, M.B. Kebaetse, O. Makgabana-Dintwa, P. Kebaabetswe, L. Badlangana, M. Mogodi, K. Bryant, O. Nkomazana, Establishing a New Medical School, Acad. Med. 89 (2014) S83-S87, doi:10.1097/acm.0000000000000329.

[52] M.A. Rahman, S.M.R. Amin, A.M.S. Alam, Removal of methylene blue from waste water using activated carbon prepared from rice husk, 60 (2) (2012) 185-189, doi:10.3329/dujs.v60i2.11491.

[53] K. Belay, M. Abebe, Removal of malachite green from aqueous solutions by adsorption using low cost boisorbent neem leaf (Azadirachta indica), Merit Res. J. Environ. Sci. Toxicol. 2 (2014) 86-92, doi:10.13140/RG.2.1.1354.5685

[54] R. Srivastava, D.C. Rupainwar, A comparative evaluation for adsorption of dye on neem bark and mango bark powder, Indian J. Chem. Technol. 18 (2011) 67-75

[55] M.A. Ahmad, N.S. Afandi, K.A. Adegoke, O.S. Bello, Optimization and batch studies on adsorption of malachite green dye using rambutan seed activated carbon, Desalin. Water Treat 57 (2016) 21487-21511, doi:10.1080/19443994.2015.1119744.

[56] M.A. Ahmad, N. Ahmad, O.S. Bello, Adsorptive removal of malachite green dye using durian seed-based activated carbon, Water. Air. Soil Pollut. 225 (2014) 2057-2076, doi:10.1007/s11270-014-2057-z.

[57] M.A. Ahmad, N. Ahmad, O.S. Bello, Modified durian seed as adsorbent for the removal of methyl red dye from aqueous solutions, Appl. Water Sci. 5 (2015) 407-423, doi:10.1007/s13201-014-0208-4.

[58] M.A. Ahmad, N. Ahmad, O.S. Bello, Statistical optimization of adsorption process for removal of synthetic dye using watermelon rinds, Model. Earth Syst. Environ. 3 (2017) 1-9, doi:10.1007/s40808-017-0269-0.

[59] M.A. Ahmad, N.S. Afandi, O.S. Bello, Optimization of process variables by response surface methodology for malachite green dye removal using lime peel activated carbon, Appl. Water Sci. 7 (2017) 717-727, doi:10.1007/s13201-015-0284-0.

[60] O. Üner, Ü. Geçgel, H. Kolancilar, Y. Bayrak, Adsorptive removal of Rhodamine B with activated carbon obtained from okra wastes, Chem. Eng. Commun. 204 (2017) 772-783, doi:10.1080/00986445.2017.1319361.

[61] O.S. Bello, S. Banjo, Equilibrium, kinetic, and quantum chemical studies on the adsorption of Congo red using imperata cylindrica leaf powder activated carbon, Toxicol. Environ. Chem. 94 (2012) 1114-1124, doi:10.1080/02772248.2012.691504.

[62] T. Murugan, A. Ganapathi, R. Valliappan, Removal of dyes from aqueous solution by adsorption on biomass of mango (Mangifera Indica) leaves, 7 (3) (2010) 669-676.

[63] T.A. Ojo, A.T. Ojedokun, O.S. Bello, Functionalization of powdered walnut shell with orthophosphoric acid for congo red dye removal, Part. Sci. Technol. 37 (2019) 74-85, doi:10.1080/02726351.2017.1340914.

[64] J. Shah, M. Rasul Jan, A. Haq, Y. Khan, Removal of rhodamine b from aqueous solutions and wastewater by walnut shells: kinetics, equilibrium and thermodynamics studies, Front. Chem. Sci. Eng. 7 (2013) 428-436, doi:10.1007/s11705-013-1358-X.

[65] M. Thirumavalavan, Y.L. Lai, L.C. Lin, J.F. Lee, Cellulose-based native and surface modified fruit peels for the adsorption of heavy metal ions from aqueous solution: langmuir adsorption isotherms, J. Chem. Eng. Data. 55 (2010) 1186-1192, doi:10.1021/je900585t.

[66] K. Amel, M.A. Hassen, D. Kerroum, Isotherm and kinetics study of biosorption of cationic dye onto banana peel, Energy Procedia (2012) 286-295, doi:10.1016/j.egypro.2012.05.208.

[67] S. Thambiraj, G. Sharmila, D. Ravi Shankaran, Green adsorbents from solid wastes for water purification application, Mater. Today Proc. (2018) 1667516683, doi:10.1016/j.matpr.2018.06.029.

[68] S.N. Jain, P.R. Gogate, Acid blue 113 removal from aqueous solution using novel biosorbent based on NaOH treated and surfactant modified fallen leaves of Prunus dulcis, J. Environ. Chem. Eng. 5 (2017) 3384-3394, doi:10.1016/j.jece.2017.06.047.

[69] H.B. Senturk, D. Ozdes, C. Duran, Biosorption of Rhodamine 6G from aqueous solutions onto almond shell (Prunus dulcis) as a low cost biosorbent, Desalination 252 (2010) 81-87, doi:10.1016/j.desal.2009.10.021. 
[70] M. Ahmaruzzaman, M.J.K. Ahmed, S. Begum, Remediation of Eriochrome black T-contaminated aqueous solutions utilizing H3PO4-modified berry leaves as a non-conventional adsorbent, Desalin. Water Treat. 56 (2015) 1507-1519, doi:10.1080/19443994.2014.950995.

[71] A. Mittal, J. Mittal, A. Malviya, V.K. Gupta, Removal and recovery of Chrysoidiney from aqueous solutions by waste materials, J. Colloid Interface Sci. 344 (2010) 497-507, doi:10.1016/j.jcis.2010.01.007.

[72] V.K. Gupta, C.K. Jain, I. Ali, S. Chandra, S. Agarwal, Removal of lindane and malathion from wastewater using bagasse fly ash - A sugar industry waste, Water Res 36 (2002) 2483-2490, doi:10.1016/S0043-1354(01)00474-2

[73] O.S. Bello, K.A. Adegoke, O.O. Akinyunni, Preparation and characterization of a novel adsorbent from Moringa oleifera leaf, Appl. Water Sci. 7 (2017) 1295-1305, doi:10.1007/s13201-015-0345-4.

[74] O.S. Bello, B.M. Lasisi, O.J. Adigun, V. Ephraim, Scavenging Rhodamine B dye using Moringa Oleifera seed pod, Chem. Speciat. Bioavailab 29 (2017) 120-134, doi:10.1080/09542299.2017.1356694.

[75] S.S. Azhar, A.G. Liew, D. Suhardy, K.F. Hafiz, M..I. Hatim, Dye removal from aqueous solution by using adsorption on treated sugarcane bagasse, Am. J. Appl. Sci. 2 (2009) 1499-1503, doi:10.3844/ajassp.2005.1499.1503.

[76] A. Bafana, S.S. Devi, T. Chakrabarti, Azo dyes: past, present and the future, Environ. Rev. 19 (2011) 350-371, doi:10.3390/s17102326.

[77] M.A. Mahmoud, A. Poncheri, Y. Badr, M.G. Abd El Waned, Photocatalytic degradation of methyl red dye, S. Afr. J. Sci. 154 (2009) 245-253, doi:10. 1016/j.jhazmat.2007.10.020.

[78] H.A. Abdulhussein, A.A. Hassan, Methyl red dye removal from aqueous solution by adsorption on rice hulls, J. Babylon Univ. Sci. 23 (2015) 627-637.

[79] M.R.H. Mas Haris, K. Sathasivam, The removal of methyl red from aqueous solutions using banana pseudostem fibers, Am. J. Appl. Sci. 6 (2009) 1690-1700, doi:10.3844/ajassp.2009.1690.1700.

[80] Z. Ioannou, C. Karasavvidis, A. Dimirkou, V. Antoniadis, Adsorption of methylene blue and methyl red dyes from aqueous solutions onto modified zeolites, Water Sci. Technol. 67 (2013) 1129-1136, doi:10.2166/wst.2013.672.

[81] Z. Aksu, Application of biosorption for the removal of organic pollutants: a review, Process Biochem 40 (2005) 997-1026, doi:10.1016/j.procbio.2004. 04.008.

[82] B.H. Hameed, F.B.M. Daud, Adsorption studies of basic dye on activated carbon derived from agricultural waste: Hevea brasiliensis seed coat, Chem. Eng. J. 139 (2008) 48-55, doi:10.1016/j.cej.2007.07.089.

[83] A.T. Ojedokun, O.S. Bello, Kinetic modeling of liquid-phase adsorption of Congo red dye using guava leaf-based activated carbon, Appl. Water Sci. 7 (2017) 1965-1977, doi:10.1007/s13201-015-0375-y.

[84] O.S. Bello, M.A. Ahmad, Preparation and characterization of activated carbon derived from rubber seed coat, Chemistry (Easton) 21 (2012) 389-395.

[85] S. Banerjee, M.C. Chattopadhyaya, Adsorption characteristics for the removal of a toxic dye, tartrazine from aqueous solutions by a low cost agricultural by-product, Arab. J. Chem. 10 (2017) S1629-S1638, doi:10.1016/j.arabjc.2013.06.005.

[86] O.S. Bello, Adsorptive removal of malachite green with activated carbon prepared from oil palm fruit fibre by KOH activation and CO2 gasification, S. Afr. J. Chem. 66 (2013) 32-41

[87] D. Pathania, S. Sharma, P. Singh, Removal of methylene blue by adsorption onto activated carbon developed from Ficus carica bast, Arab. J. Chem. 10 (2017) S1445-S1451, doi:10.1016/j.arabjc.2013.04.021.

[88] Z. Anfar, R. El Haouti, S. Lhanafi, M. Benafqir, Y. Azougarh, N. El Alem, Treated digested residue during anaerobic co-digestion of Agri-food organic waste: Methylene blue adsorption, mechanism and CCD-RSM design, J. Environ. Chem. Eng. 5 (2017) 5857-5867, doi:10.1016/j.jece.2017.11.015.

[89] O.S. Bello, M.A. Ahmad, Coconut (Cocos nucifera) shell based activated carbon for the removal of malachite green dye from aqueous solutions, Sep. Sci. Technol. 47 (2012) 903-912, doi:10.1080/01496395.2011.630335.

[90] O.A. Ekpete, M. Horsfall, Kinetic sorption study of phenol onto activated carbon derived from fluted pumpkin stem waste (Telfairia occidentalis Hook. F), ARPN J. Eng. Appl. Sci. 6 (6) (2011) 43-49.

[91] O.S. Bello, K.A. Adegoke, O.O. Akinyunni, Preparation and characterization of a novel adsorbent from Moringa oleifera leaf, Appl. Water Sci. 7 (2017) 1295-1305, doi:10.1007/s13201-015-0345-4.

[92] M. Horsfall Jnr, Preparation and characterization of activated carbon derived from fluted pumpkin stem waste (Telfairia occidentalis Hook F), Res. J. Chem. Sci. 1 (3) (2011) 10-17.

[93] O.S. Bello, T.T. Siang, M.A. Ahmad, Adsorption of Remazol brilliant Violet-5R reactive dye from aqueous solution by cocoa pod husk-based activated carbon: kinetic, equilibrium and thermodynamic studies, Asia-Pacific J. Chem. Eng. 7 (2012) 378-388, doi:10.1002/apj.557.

[94] A. Khasri, O.S. Bello, M.A. Ahmad, Mesoporous activated carbon from pentace species sawdust via microwave-induced KOH activation: optimization and methylene blue adsorption, Res. Chem. Intermed. 44 (2018) 5737-5757, doi:10.1007/s11164-018-3452-7.

[95] I.A.W. Tan, A.L. Ahmad, B.H. Hameed, Adsorption of basic dye on high-surface-area activated carbon prepared from coconut husk: equilibrium, kinetic and thermodynamic studies, J. Hazard. Mater. 154 (2008) 337-346, doi:10.1016/j.jhazmat.2007.10.031.

[96] M.A. Ahmad, O.S. Bello, M.A. Ahmad, Adsorption studies of Remazol brilliant blue r dye on activated carbon prepared from corncob, Am. J. Mod. Chem. Eng. 1 (2014) 1-12.

[97] E. Demirbas, M.Z. Nas, Batch kinetic and equilibrium studies of adsorption of reactive blue 21 by fly ash and sepiolite, Desalination 243 (2009) $8-21$, doi:10.1016/j.desal.2008.04.011.

[98] M.S. Chiou, H.Y. Li, Equilibrium and kinetic modeling of adsorption of reactive dye on cross-linked chitosan beads, J. Hazard. Mater. 93 (2002) 233248, doi:10.1016/S0304-3894(02)00030-4

[99] R.A. Koble, T.E. Corrigan, Adsorption Isotherms for Pure Hydrocarbons, Ind. Eng. Chem. (1952), doi:10.1021/ie50506a049.

[100] W.R. Vieth, K.J. Sladek, A model for diffusion in a glassy polymer, J. Colloid Sci. (1965), doi:10.1016/0095-8522(65)90071-1

[101] C.J. Radke, J.M. Prausnitz, C.J. Radke, Adsorption of Organic Solutes from Dilute Aqueous Solution on Activated Carbon, Ind. Eng. Chem. Fundam. (1972), doi:10.1021/i160044a003.

[102] S.J. Gregg, K.S.W. Sing, H.W. Salzberg, Adsorption Surface Area and Porosity, J. Electrochem. Soc. (1967), doi:10.1149/1.2426447.

[103] S. Lagergren, About the theory of so-called adsorption of soluble substances, Handlingar (1898), doi:10.1023/B.

[104] Y.S. Ho, G. McKay, Pseudo-second order model for sorption processes, Process Biochem. (1999), doi:10.1016/S0032-9592(98)00112-5.

[105] C. Aharoni, M. Ungarish, Kinetics of activated chemisorption. Part 2. - Theoretical models, J. Chem. Soc. Faraday Trans. 1 Phys. Chem. Condens. Phases. (1977), doi:10.1039/F19777300456.

[106] M. Ungarish, C. Aharoni, Kinetics of chemisorption. Deducing kinetic laws from experimental data, J. Chem. Soc. Faraday Trans. 1 Phys. Chem. Condens. Phases (1981), doi:10.1039/F19817700975

[107] M. Avrami, Kinetics of phase change. II Transformation-time relations for random distribution of nuclei, J. Chem. Phys. (1940), doi:10.1063/1.1750631.

[108] G.E. Boyd, J. Schubert, A.W. Adamson, The Exchange Adsorption of Ions from Aqueous Solutions by Organic Zeolites. Ion-exchange Equilibria, J. Am. Chem. Soc. (1947), doi:10.1021/ja01203a064. 